\begin{tabular}{c} 
Jurnal Inovasi Pembelajaran Fisika \\
(INPAFI) \\
$\begin{array}{c}\text { Available online http://jurnal.unimed.ac.id/2012/index.php/inpafi } \\
\text { e-issn 2549-8258, p-issn 2337-4624 }\end{array}$ \\
\hline
\end{tabular}

\title{
PENGARUH MODEL PEMBELAJARAN KOOPERATIF TIPE GROUP INVESTIGATION TERHADAP PENGETAHUAN KONSEPTUAL SISWA PADA MATERI SUHU DAN KALOR
}

\author{
Widya Avelia M dan Makmur Sirait \\ Jurusan Fisika FMIPA Universitas Negeri Medan \\ aveliawidia@yahoo.co.id
}

Diterima: September 2018. Disetujui: Oktober 2018. Dipublikasikan: Februari 2019

\begin{abstract}
ABSTRAK
Penelitian ini bertujuan untuk mengetahui pengaruh model pembelajaran kooperatif tipe GI terhadap pengetahuan konseptual dan aktivitas siswa pada materi suhu dan kalor. Jenis penelitian ini adalah quasi exsperiment dengan menggunakan two group pretest-posttest design. Sampel penelitian terdiri dari dua kelas, yang masing-masing berjumlah 32 siswa di SMA Free Methodist 1 Medan, pengambilan sampel dilakukan dengan teknik random sampling. Instrumen yang digunakan adalah tes berupa pengetahuan konseptual siswa dalam bentuk esai sebanyak 10 soal. Nilai rata-rata aktivitas belajar siswa kelas eksperimen dalam empat kali pertemuan menunjukan peningkatan. Nilai rata-rata postes eksperimen adalah 75,15 dan kelas kontrol adalah 59,53. Setelah diuji dengan uji t menunjukkan bahwa ada pengaruh yang signifikan model pembelajaran kooperatif tipe group investigation terhadap pengetahuan konseptual siswa pada materi suhu dan kalor di kelas X Semester II SMA Free Methodist 1 Medan T.P 2017/2018.
\end{abstract}

Kata kunci : Model group investigation, aktivitas, pengetahuan konseptual.

\begin{abstract}
This study aims to determine the effect of cooperative learning model type of group investigation on student's conceptual knowledge and activies in the subject temperature and heat. This research is a quasi experiment using two group pretest-posttest design. The study sampel consisted of two classes, each of which amounted to 32 students at SMA Free Methodist 1 Medan, the sampling be done with random sampling technique. The instrument used was a test of learning outcomes in the form of students conceptual knowledge in the form of 10 esay tes. The average value of students experimental learning activities in four meetings showed an increase. The value of the average post-test experimental class was 75,15 and 59,53 control class. Hypothesis with t-test shows the result there was a significant influence of cooperative learning model type group investigation to conceptual knowledge student subject of temperature and heat in class X SMA Free Methodist 1 Medan T.P $2017 / 2018$.
\end{abstract}

Keywords: Group investigation model, activities, conceptual knowledge 


\section{PENDAHULUAN}

Pendidikan merupakan kebutuhan manusia selama hidup. Tanpa adanya pendidikan, maka dalam menjalani kehidupan ini tidak akan dapat berkembang. Pendidikan itu harus betulbetul diarahkan untuk menghasilkan manusia yang berkualitas yang mampu bersaing, memiliki budi perkerti yang luhur dan moral yang baik. Pendidikan yang terencana, terarah dan berkesinambungan dapat membantu siswa untuk mengembangkan kemampuan secara optimal, baik aspek kognitif, aspek afektif, maupun aspek psikomotorik, perlu diupayakan suatu sistem pendidikan yang mampu membentuk kepribadian dan keterampilan siswa yang unggul, yakni manusia yang kreatif, cakap terampil, jujur, dapat dipercaya, bertanggung jawab dan memiliki solidaritas yang tinggi (Triyanto, 2013).

Fisika merupakan suatu ilmu pengetahuan yang mempelajari gejala-gejala alam dan interaksi di dalamnya, gejala dan fenomena yang terjadi di alam tidak dapat dipisahkan dari kemajuan ilmu pengetahuan dan teknologi itu sendiri. Pemilihan sistem pembelajaran yang tepat, termasuk di dalamnya materi, metode dan media pembelajaran yang digunakan selama proses pembelajaran akan dapat mengatasi kendala-kendala dalam pelaksanaan pembelajaran sehingga mendukung peningkatan sumber daya manusia yang mampu berpikir kritis, kreatif, logis dan berinisiatif untuk kemajuan teknologi itu sendiri (Simamora dan Simamora, 2018).

Berdasarkan studi pendahuluan yang dilakukan dengan cara menyebarkan menggunakan instrumen angket kepada 32 orang siswa di SMA Free Methodist 1 Medankelas X semester IIdiperoleh data sebagai berikut: 75\%siswa jarang mengemukakan pendapat karena guru lebih dominan menggunakan metode ceramah, 78,12\% siswa juga mengatakan bahwa jarang melakukan diskusi kelompok, dan $87,5 \%$ siswa menginginkan belajar sambil berdiskusi dan melakukan pratikum ataupun demonstrasi. Berdasarkan wawancara dengan salah seorang guru fisika kelas $\mathrm{X}$ di SMA Free Methodist 1 Medan mengatakan bahwa pengetahuan konseptual siswa masih rendah ditunjukkan pada rata-rata nilai mereka di bawah kriteria ketuntasan minium (KKM).

Menurut Arends (2008) pengetahuan konseptual merupakan pengetahuan yang menunjukkan saling keterkaitan antara unsurunsur dasar dalam struktur yang lebih besar dan berfungsi secara bersamaan. Pengetahuan konseptual terdiri dari tiga subjenis, yaitu pengetahuan tentang klasifikasi dan kategori, pengetahuan tentang prinsip dan generalisasi, dan pengetahuan tentang teori, model dan struktur. Klasifikasi dan kategori merupakan landasan bagi prinsip dan generalisasi, prinsip dan generalisasi pada gilirannya menjadi dasar bagi teori, struktur dan model. Tiga subjenis ini melingkupi banyak sekali pengetahuan mengemukakan dasar disiplin ilmu (Anderson dan Krathwohl, 2001).

Selain itu ada beberapa faktor yang menjadi penyebab nilai siswa di bawah KKM, salah satunya adalah model pembelajaran yang digunakan kurang bervariasi dan pembelajaran yang berpusat pada guru (teacher centered), sehingga guru cendrung aktif pada proses pembelajaran dan siswa sebagai pendengar. Akibtanya siswa hanya menghapal tanpa mengerti apa yang dipelajari dan hubungannya dalam kehidupan sehari-hari.

Berdasarkan permasalahan di atas, perlu diupayakan solusinya yaitu dengan menggunakan model dan metode pembelajaran yang dapat meningkatkan minat, semangat, kemampuan untuk dapat bekerja sama dengan teman dalam memecahkan suatu permasalahan fisika, dan yang dapat membuat siswa terlibat aktif dalam proses pembelajaran. Model dan metode tersebut juga harus disesuaikan dengan tujuan pembelajaran dan materi pelajaran yang diajarkan.

Salah satu model pembelajaran yang perlu dikembangkan yang diharapkan dapat meningkatkan hasil belajar siswa melalui penerapan bekerja sama memecahkan masalah, menemukan sesuatu untuk dirinya dan saling mendiskusikan masalah tersebut dengan temantemannya yaitu dengan menerapkan model pembelajaran kooperatif tipe GI. Model 
pembelajaran kooperatif tipe GI adalah sebuah model yang melibatkan siswa dalam merencanakan topik-topik yang akan dipelajari dan bagaimana menjalankan investigasinya (Arends, 2008).

Model pembelajaran GI siswa dilibatkan dalam perencanaan topik yang akan di pelajari dan bagaimana penyelidikan yang akan dilakukan. Siswa akan dilatih untuk berfikir ilmiah dalam menghadapi permasalahan dan berusaha memecahkannya. Guru berperan sebagai fasilitator dalam membimbing siswa menyelesaikan materi atau tugas. Keberhasilan pelaksanaan investigasi kelompok sangat tergantung dengan latihan-latihan berkomunikasi dan berbagai keterampilan sosial lain yang dilakukan sebelumnya (Sari dan Eurika, 2016).

Penelitian model kooperatif tipe group investigation telah dilakukan sebelumnya oleh Tumanggor dan Sahyar (2015) menyatakan bahwa model pembelajaran kooperatif tipe group investigation baik diterapkan pada siswa yang mempunyai sikap ilmiah tinggi dan Siregar dan Harahap (2016) menyatakan bahwa model GI memiliki pengaruh yang lebih baik terhadap hasil belajar pengetahuan konseptual siswa daripada pembelajaran konvensional.

Tujuan penelitian adalah untuk mengetahui pengaruh model pembelajaran kooperatif tipe GI terhadap pengetahuan konseptual siswa pada materi pokok suhu dan kalor di kelas X Semeseter II SMA Free Methodist 1 Medan T.P. 2017/2018.

\section{METODE PENELITIAN}

Penelitian ini dilaksanakan di SMA Free Methodist 1 Medan di Jl. Beringin Raya No. 152 E untuk kelas $\mathrm{X}$ semester II T.P. 2017/2018.Populasi dalam penelitian ini adalah seluruh siswa kelas X SMA Free Methodist 1 Medan terdiri 4 kelas. Sampel dalam penelitian ini terdiri dari dua kelas yang masing-masing berjumlah 32 siswa yang dipilih secara acak dengan teknik random sampling yang melibatkan dua kelas yang diberikan pelakukan yang berbeda. Kelas X MIA 1 dengan menggunakan model kooperatif tipe group investigation dan kelas X MIA 2 dengan menggunakan model konvensional.

Desain penelitian yang digunakan adalah two group pretest - posttest design. Desain penelitian ditunjukkan pada Tabel 1.

Tabel 1. two group pretest - posttest design

\begin{tabular}{|l|c|c|c|}
\hline \multicolumn{1}{|c|}{ Kelas } & Pretes & Perlakuan & Postes \\
\hline Eksperimen & $\mathrm{T}_{1}$ & $\mathrm{X}_{1}$ & $\mathrm{~T}_{2}$ \\
\hline Kontrol & $\mathrm{T}_{1}$ & $\mathrm{X}_{2}$ & $\mathrm{~T}_{2}$ \\
\hline
\end{tabular}

Keterangan:

$\mathrm{T}_{1}=$ tes kemampuan awal (pretes)

$\mathrm{T}_{2}=$ tes kemampuan akhir (postes)

$\mathrm{X}=$ perlakuan pada kelas eksperimen yaitu penerapan model kooperatif tipe GI

$\mathrm{Y}=$ perlakuan pada kelas kontrol yaitu penerapan model pembelajaran konvensional (Sudjana, 2005).

Peneliti memberikan pretes dan postes pada kelas eksperimen dan kelas kontrol. Instrumen yang digunakan pada penelitian adalah tes pengetahuan konseptual yang terdiri dari 10 soal tes essai yang sudah distandarisasi dengan menggunakan uji validitas isi oleh dua orang dosen dan uji validitas konstruk dan lembar observasi aktivitas siswa. Indikator aktivitas belajar siswa meliputi memilih topik, merencanakan kooperatif, mengumpulkan data eksperimen, menganalisis data percobaan, mempresentasikan hasil percobaan, dan merumuskan kesimpulan (Arends, 2008). Setelah data pretes diperoleh, dilakukan analisis data dengan uji normalitas yaitu uji Lilliefors, uji homogenitas dan uji $\mathrm{t}$ untuk mengetahui kemampuan awal siswa pada kedua kelompok sampel dalam hal ini kemampuan kedua kelompok sampel harus sama. Selanjutnya peneliti mengajarkan materi pelajaran dengan menggunakan model kooperatif tipe GI pada kelas eksperimen dan pada kelas kontrol menggunakan pembelajaran konvensional. Perbedaan hasil akhir dapat diketahui dengan melakukan uji postes menggunakan uji t satu pihak untuk mengetahui pengaruh model kooperatif tipe GI terhadap pengetahuan konseptual siswa. 


\section{HASIL DAN PEMBAHASAN}

\section{a. Hasil Penelitian}

Penelitian ini merupakan penelitian eksperimen yang melibatkan dua kelas yang diberi model pembelajaran yang berbeda yaitu kelas eksperimen yang diajar dengan model pembelajaran kooperatif tipe GI dan kelas kontrol diajar dengan model pembelajaran konvensional. Sebelum kedua kelas diterapkan perlakuan yang berbeda, maka pada kedua kelas terlebih dahulu diberikan pretes yang bertujuan untuk mengetahui kemampuan awal belajar siswa pada masing-masing kelas.

Hasil penelitian yang dilakukan di SMA Free Methodist 1 Medan diperoleh nilai rata-rata pretes siswa pada kelas eksperimen sebelum diberi perlakuan dengan menggunakan model pembelajaran kooperatif tipe GI sebesar 39,92 dan di kelas kontrol diperoleh nilai rata-rata pretes sebesar 39,21. Sesuai dengan uji normalitas dan uji homogenitas diperoleh bahwa sampel berasal dari populasi yang berdistribusi normal dan homogen. Distribusi nilai pretes kelas eksperiman dan kontrol dapat dilihat pada gambar 1.

\section{w' Frekuensi Kontrol $\square$ Frekuensi Eksperimen}

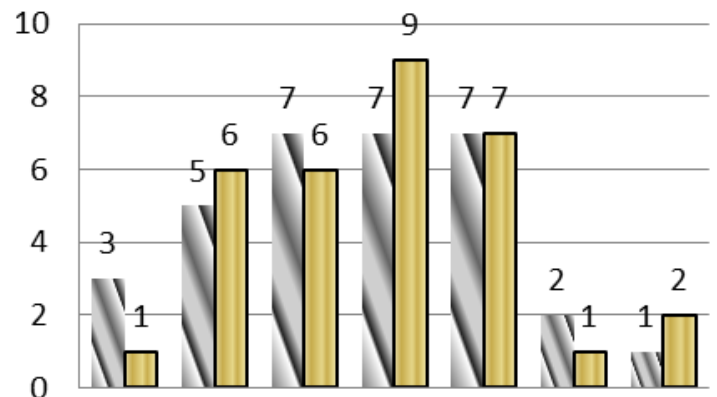

25-29 30-34 35-39 40-44 45-49 50-54 55-59

Gambar 1. Grafik distribusi nilai pretes kelas eksperimen dan kontrol

Data kedua sampel dinyatakan normal dan homogen sehingga layak dilakukan uji hipotesis dan hasilnya ditunjukkan pada Tabel 2.

\begin{tabular}{|l|l|l|l|l|}
\hline Kelas & $\begin{array}{l}\text { Rata- } \\
\text { Rata }\end{array}$ & thitung & tabel & $\begin{array}{l}\text { Kesimpula } \\
\mathrm{n}\end{array}$ \\
\hline
\end{tabular}

\begin{tabular}{|l|c|c|c|c|}
\hline $\begin{array}{l}\text { Eksperime } \\
\mathrm{n}\end{array}$ & 39,92 & 0,391 & 1,999 & $\begin{array}{c}\mathrm{H}_{\mathrm{o}} \\
\text { diterima }\end{array}$ \\
\hline Kontrol & 39,21 & & & 0,0 \\
\hline
\end{tabular}

Berdasarkan Tabel 2 dapat disimpulkan bahwa thitung < ttabel maka, thitung jatuh pada daerah Ho maka Ho diterima yaitu kemampuan awal siswa pada kelas eksperimen sama dengan kemampuan awal siswa pada kelas kontrol pada mataeri suhu dan kalor. Masing-masing kelas diberikan perlakuan yang berbeda kelas eksperimen dengan menggunakan model GI dan kelas kontrol menggunakan pembelajaran konvensional. Setelah diberi perlakuan, siswa diberikan postes. Dari hasil postes kedua sampel dinyatakan normal dan homogen sehingga layak dilakukan uji hipotesis dan hasilnya ditunjukkan pada Tabel 3.

Tabel 3. Hasil Uji Hipotesis Penelitian

\begin{tabular}{|l|l|l|l|l|}
\hline Kelas & $\begin{array}{l}\text { Rata- } \\
\text { Rata }\end{array}$ & thitung & ttabel & Kesimpulan \\
\cline { 1 - 2 } Eksperimen & 75,15 & \multirow{2}{*}{8,437} & 1,669 & $\mathrm{H}_{\text {a diterima }}$ \\
\hline Kontrol & 59,53 & & \\
\hline
\end{tabular}

Berdasarkan Tabel 3 dapat disimpulakan bahwa thitung $<$ tabel yaitu 8,437>1,669 artinya $\mathrm{H}_{\mathrm{o}}$ ditolak dan $\mathrm{H}_{\mathrm{a}}$ diterima maka nilai hasil belajar siswa kelas eksperimen lebih besar dari pada kelas kontrol yang artinya ada pengaruh yang signifikan model pembelajaran kooperatif tipe group investigation (GI) terhadap pengetahuan konseptual siswa dikelas X SMA Free Methodist 1 Medan T.P. 2017/2018.

Selain dari nilai pretes dan postes, aktivitas belajar siswa juga dikaji dalam penelitian ini untuk mendeskripsikan perkembangan aktivitas siswa selama proses pembelajaran berlangsung. Distribusi data aktivitas kelas eksperimen dengan menggunakan model pembelajaran kooperatif tipe group investiagtion ditunjukkan pada Tabel 4.

Tabel 4. Data aktivitas kelas eksperimen

\begin{tabular}{|c|c|c|}
\hline Pertemuan & $\begin{array}{c}\text { Nilai Rata- } \\
\text { Rata }\end{array}$ & Kategori \\
\hline Pertemuan I & 59,72 & Cukup aktif \\
\hline
\end{tabular}


Widya Avelia M dan Makmur Sirait; Pengaruh Model Pembelajaran Kooperatif Tipe Group Investigation Terhadap Pengetahuan Konseptual Siswa Pada Materi Suhu Dan Kalor

\begin{tabular}{|c|c|c|}
\hline Pertemuan II & 60,24 & Cukup aktif \\
\hline Pertemuan III & 65,97 & Cukup aktif \\
\hline Pertemuan IV & 68,05 & Cukup aktif \\
\hline
\end{tabular}

Berdasarkan Tabel 4 untuk kelas eksperimen aktivitas siswa pertemuan I yaitu 59,72 tergolong cukup aktif. Pertemuan II terjadi peningkatan menjadi 60,24 yaitu pada kategori cukup aktif, pertemuan III yaitu 65,97 pada kategori cukup aktif. Selanjutnya, pertemuan IV juga terjadi peningkatan aktivitas siswa menjadi 68,05 pada kategori cukup aktif.

Data peningkatan aktivitas siswa dengan menggunakan model pembelajaran kooperatif tipe GI menunjukkan bahwa untuk kelas eksperimen dari pertemuan I sampai pertemuan IV aktivitas belajar dengan menggunakan model pembelajaran kooperatif tipe GI mengalami peningkatan. Hal ini aktivitas siswa memiliki pengaruh yang positif terhadap pengetahuan konseptual siswa.

\section{b. Pembahasan}

Model pembelajaran tipe group investigation dapat meningkatkan pengetahuan konseptual siswa dan aktivitas siswa yang lebih aktif dalam proses pembelajaran. Adanya peningkatan pengetahuan konseptual siswa disebabkan oleh kelebihan model pembelajaran kooperatif tipe GI yang tidak hanya mengharuskan siswa untuk mendengarkan dan menghafal tetapi sebuah model yang membimbing siswa untuk merencanakan dan mengorganisasikan pekerjaannya dan mengecek kebenaran jawaban yang mereka buat.

Selama proses pembelajaran berlangsung didominasi kegiatan diskusi dengan kelompok yang anggotanya heterogen, kemudian siswa diberikan LKS sebagai media belajar yang sudah disediakan, kemudian siswa mencari sendiri jawaban-jawaban dari LKS tersebut. Model pembelajaran GI mengharuskan siswa untuk memiliki kemampuan yang baik dalam berkomunikasi maupun dalam keterampilan proses. Selain itu, siswa juga akan bertukar informasi, saling membantu menjelaskan kepada teman yang belum mengerti tanpa ada rasa malu dan takut karena mereka berpendapat kepada temannya sendiri, sehingga mereka juga belajar tentang bagaimana bersosialisasi dengan teman. Hal ini juga didukung oleh hasil penelitian Lumbantoruan dan Sirait (2016) yang menyatakan bahwa model kooperatif tipe GI juga memberi kesempatan kepada anggota kelompok untuk mengambil bagian dalam merencanakan berbagi dimensi dan tuntutan dari proyek mereka.

Model pembelajaran kooperatif tipe GI juga dapat meningkatkan aktivitas belajar siswa. Hal ini didukung oleh penelitian Harahap dan Turnip (2014) yang menyatakan adanya peningkatan aktivitas belajar siswa saat model pembelajaran kooperatif tipe GI.

Selama penerapan model Kooperatif Tipe Group Investigation di kelas eksperimen, peneliti dibantu oleh dua orang observer untuk menilai aktivitas belajar siswa. Aktivitas belajar siswa yang dinilai pada fase pemilihan topik, perencanaan kooperatif, implementasi, analisis dan sintesis, presentasi dan evaluasi disesuaikan dengan sintaks model Kooperatif Tipe Group Investigation. Aktivitas belajar siswa dinilai selama empat pertemuan. Perkembangan aktivitas dari pertemuan I, II, III, dan IV diperoleh rata-rata perkembangan aktivitas 59,72; 60,24; 65,97; 68,05 semakin naik nilai rata-rata tiap pertemuan dengan kategori cukup aktif. Model GI dapat meningkatkan aktivitas siswa karena pada tiap langkah pembelajaran siswa dilibatkan secara langsung. Sejalan pada peneliitian Silviana (2017) yang menyatakan bahwa siswa dari awal kegiatan pembelajaran mulai aktif dengan menemukan sendiri konsepkonsep fisika yang dikonstruksi oleh siswa, sehingga pengetahuan konseptual siswa melalui model pembelajaran kooperatif tipe GI lebih baik dibandingkan dengan pembelajaran konvensional.

Berbeda dengan pembelajaran pada kelas kontrol yang menggunakan pembelajaran konvensional. Siswa ditempatkan sebagai objek belajar yang berperan sebagai penerima informasi secara pasif, siswa lebih banyak belajar dengan menerima, mencatat, dan menghafal materi pelajaran. Pada kelas kontrol guru merupakan pemberi informasi sedangkan siswa sebagai penerima informasi secara pasif. Pembelajaran 
hanya berpusat pada guru sehingga cenderung menjadi penentu jalannya proses pembelajaran. Pembelajaran dengan menggunakan model pembelajaran kooperatif tipe GI siswa yang menjadi pusat pembelajaran. Sejalan pada Lumbantoruan dan Sirait (2016) pembelajaran model kooperatif menekankan pada kesadaran siswa dalam belajar berfikir, aktif melakukan investigasi, belajar mengaplikasikan pengetahuan dan keterampilan serta saling berbagi pengetahuan, konsep, dan keterampilan tersebut kepada siswa yang lainnya, dan didukung juga oleh Dwi dan Arif (2013) menyatakan bahwa model pembelajaran kooperatif tipe GI membuat siswa lebih kreatif.

Kendala-kendala dalam penerapan model pembelajaran kooperatif tipe GI selama kegiatan berlangsung, diantaranya yaitu pada saat pembelajaran menggunakan model GI siswa masih ribut dalam pembentukan kelompok yang berpengaruh pada waktu pelajaran yang tersedia, pada saat pelaksanaan berlangsung ada beberapa anggota kelompok yang kurang aktif dalam hal kerjasama untuk mengerjakan LKS saat diskusi, sehingga LKS yang diberikan lambat untuk diselesaikan, ada beberapa siswa yang masih malu dalam mengemukakan pendapat, sehingga dapat menghambat proses pembelajaran berlangsung, dan siswa juga masih kurang terbiasa menggunakan metode eksperimen karena selama belajar guru bidang studi fisika hanya menggunakan metode ceramah.

Hasil pengamatan selama melaksanakan penelitian, tampak bahwa semangat dan pengetahuan konseptual siswa yang diajar dengan model pembelajaran kooperatif tipe GI lebih baik jika dibandingkan dengan siswa yang diajar dengan menggunakan model pembelajaran konvensional.

\section{a. Kesimpulan}

KESIMPULAN DAN SARAN

Berdasarkan hasil penelitian yang diperoleh dapat disimpulkan bahwa ada pengaruh model pembelajaran kooperatif tipe GI terhadap pengetahuan konseptual siswa pada materi pokok Suhu dan Kalor di kelas X Semester II
SMA Free Methodist 1 Medan T.P. 2017/2018 dan dapat meningkatkan aktivitas belajar siswa.

\section{b. Saran}

Berdasarkan pembahasan hasil penelitian saran yang dapat diajukan untuk peneliti selanjutnya yang ingin menerapkan model GI sebaiknya lebih memperhatikan efisiensi waktu di setiap fase yang tertuang pada tahap model pembelajaran kooperatif tipe GI.

\section{DAFTAR PUSTAKA}

Anderson, L. W., dan Krathwohl, D. R. (2001). Kerangka Landasan Untuk Pembelajaran dan Assesmen.Yogyakarta: Pustaka Pelajar

Arends, R. I. (2008).Laerning to Teach: Belajar Untuk Mengajar Edisi Ketujuh Buku Dua.Yogykarta: Pustaka Belajar

Dwi, I. M., danArif, H. (2013). Pengaruh Model Pembelajaran Kooperatif Tipe Group Investigation (GI) Berbatuan Media Komputer terhadap Hasil Belajar Siswa pada Materi Pokok Listrik Dinamis. Jurnal Pendidikan Fisika Indonesia. 2(4), 97-104.

Harahap, R., dan Turnip, B.M. (2014).Pengaruh Model Pembelajaran Kooperatif Tipe Group Investigation (GI) Berbantu Media Flash terhadap Hasil Belajar Fisika Siswa SMA,Jurnal Inpafi, 2(3), 156-163.

Lumbantoruan, D., dan Sirait, M. (2016).Pengaruh Model Pembelajaran Kooperatif Tipe Group Investigation (GI) Untuk Meningkatkan Hasil Belajar Siswa Pada Materi Pokok Suhu dan Kalor.Jurnal Inpafi.4(4), 15-21.

Sari, N. M., dan Eurika, N. (2016).Penerapan Model Pembelajaran Group Investigation untuk Meningkatkan Hasil Belajar Siswa.Jurnal Biologi. 1(1), 29-41. 
Widya Avelia M dan Makmur Sirait; Pengaruh Model Pembelajaran Kooperatif Tipe Group Investigation Terhadap Pengetahuan Konseptual Siswa Pada Materi Suhu Dan Kalor

Silviana, F. (2017). Efek Model Pembelajaran Kooperatif Tipe Group Investigation terhadap Kemampuan Kerjasama dan Hasil Belajar Siswa. Jurnal Pendidikan Fisika. 6(1), 39-43.

Simamora, D., dan Simamora, P. (2018).Pengaruh Model Pembelajaran Kooperatif Tipe Group Investigation Terhadap Hasil Belajar Pengetahuan Konseptual Siswa pada Materi Pokok Pengukuran di SMA Negeri 1 Pancur Batu.Jurnal Inpafi. 6(2), 10-18.

Siregar, E., dan Harahap, M,B., (2016). Pengaruh Model Pembelajaran Kooperatif Tipe Group Investigation (GI) Terhadap Pengetahuan Konseptual Siswa SMA Muhammadiyah 2 Medan T.P. 2015/2016, Jurnal Inpafi, 4(4), 38-44.

Sudjana. (2005). Metoda Statistika. Bandung: PT. Tarsito Bandung

Triyanto, E. (2013). Peran Kepemimpinan Kepala Sekolah Dalam Pemanfaatan Media Pembelajaran Sebagai Upaya Peningkatan Kualitas Proses Pembelajaran. Jurnal Teknologi Pendidikan. 1(2), 226-238.

Tumanggor, A., dan Sahyar. (2015). Analisis Model Pembelajaran Kooperatif Tipe Group Investigation Berbasis Kolaboratif Dan Sikap Ilmiah Terhadap Hasil Belajar Fisika Siswa SMAN 1 Secanggang, Jurnal Pendidikan Fisika,4(2), 21-28. 